\title{
Collagen type I in the treatment of painful osteoarthritis of the knee
}

\section{Kolagen typu I w leczeniu bolesnej choroby zwyrodnieniowej stawów kolanowych}

\author{
Roman Stančík', Jozef Zvarka1, Marián Hlaváč², Vladimír Kubinec², Jozef Rovenský \\ ${ }^{1}$ National Institute of Rheumatic Diseases, Piešt'any, Slovakia \\ 2Department of Orthopedics of F.D. Roosevelt Hospital, Banská Bystrica, Slovakia \\ ${ }^{1}$ Narodowy Instytut Chorób Reumatycznych, Pieszczany, Słowacja \\ 2Oddział Ortopedii, Szpital im. F.D. Roosevelta, Bańska Bystrzyca, Słowacja
}

Key words: collagen type I, osteoarthritis, WOMAC, visual analog scale.

Stowa kluczowe: kolagen typu I, choroba zwyrodnieniowa stawów, WOMAC, wizualna skala analogowa.

\section{Sum mary}

Background: Previous studies have shown that undenatured collagen type II is effective in the treatment of both rheumatoid arthritis and osteoarthritis (OA) of the knee. The present randomized double-blind, placebo-controlled clinical trial evaluated the safety and efficacy of collagen type I (COL-I) in the treatment of $\mathrm{OA}$ of the knee.

Material and methods: The study group consisted of 58 patients diagnosed with knee OA (Table I). The results indicate that COL-I treatment is effective in knee OA, resulting in significant reduction in the WOMAC score and pain VAS score from the baseline after 3 months treatment and after 1 month follow-up. Treatment with COL-I reduced the total WOMAC score by $38 \%$ as compared to $10 \%$ in the placebo treated group and $37 \%$ vs. $8 \%$ after 1 month follow-up. COL-I treatment decreased the pain VAS score by $41 \%$ after 3 months treatment vs $13 \%$ in the placebo treated group and after 1 month follow-up $37 \%$ vs. $11 \%$. Efficacy of the treatment evaluated by patients showed significantly better efficacy in the COL-I treated group compared to the placebo group (Fig. 1-3).

Results: The results of this study indicate that collagen type I is an effective treatment for symptomatic knee OA, even with a carry-over effect for at least 1 month. In addition, it also has a very good safety profile.

\section{Streszczenie}

Wstęp: Przeprowadzone wcześniej badania wykazały, że niezdenaturowany kolagen typu II jest skuteczny w leczeniu zarówno reumatoidalnego zapalenia stawów (RZS), jak i choroby zwyrodnieniowej (ChZ) stawu kolanowego. W przeprowadzonym metodą podwójnie ślepej próby, kontrolowanym placebo badaniu klinicznym z randomizacją autorzy ocenili bezpieczeństwo i skuteczność kolagenu typu I (COL-I) w leczeniu ChZ stawu kolanowego.

Materiał i metody: Badana grupa składała się z 58 pacjentów z rozpoznaniem ChZ stawu kolanowego (tabela I). Wyniki wskazują na skuteczność leczenia ChZ stawu kolanowego COL-I w postaci znamiennego, w porównaniu z wartościami wyjściowymi, obniżenia punktacji w skali WOMAC i skali bólu VAS po 3 miesiącach leczenia oraz po miesiącu od jego zakończenia. Terapia COL-I doprowadziła do obniżenia łącznej punktacji w skali WOMAC o 38\% w porównaniu ze spadkiem o 10\% w grupie otrzymującej placebo oraz o $37 \%$ vs 8\% po miesiącu obserwacji. Leczenie COL-I zmniejszyło dolegliwości bólowe wg skali VAS o 41\% po 3 miesiącach terapii wobec spadku o 13\% w grupie otrzymującej placebo oraz odpowiednio o 37\% vs $11 \%$ po miesiącu obserwacji. Ocena efektywności leczenia wg pacjentów wskazała na znamiennie lepszą skuteczność terapii w grupie leczonej COL-I w porównaniu z grupą otrzymującą placebo (ryc. 1-3).

Wyniki: Wyniki badania wskazują na skuteczność działania leczniczego COL-I w objawowej ChZ stawu kolanowego, charakteryzującego się nawet odległym w czasie efektem przeniesienia. Ponadto COL-I ma bardzo dobry profil bezpieczeństwa.

Address for correspondence:

Prof. Jozef Rovenský, MD, DSc, FRCP, National Institute of Rheumatic Diseases, Nábrežie I. Krasku 4, 92101 Piešt’any, Slovakia, tel. 0042133 7969111, fax 0042133 7721192, e-mail: rovensky.jozef@nurch.sk

Submitted: 15.02 .2012 


\section{Introduction}

Osteoarthritis (OA) is the most common joint disorder worldwide. In western countries, radiographic evidence of this disease is present in the majority of people after 65 years of age and in about $80 \%$ of people over 75 years of age [1]. Pain and other symptoms of OA may have a strong effect on quality of life, affecting both physical and psychological functions. It is now well recognized that OA is not solely a disease of cartilage, but also affects synovium and the underlying bone [2, 3]. The periarticular bone reacts with osteophyte formation, which causes additional restriction in joint movement. The degradation of cartilage occurs as a result of complex interactions between the mechanical factors and biochemical changes in the affected joint.

Current treatment of $\mathrm{OA}$ includes exercise, physiotherapy and medications $[4,5]$. The most common medications include analgesics and non-steroidal anti-inflammatory drugs. Although these drugs are effective for reducing pain associated with $\mathrm{OA}$, they can also cause serious gastrointestinal and cardiovascular adverse events, especially with their long-term use [6]. However, the main goal of OA therapy should be to delay cartilage degeneration and even help to regenerate the cartilage structure. Medications having these properties are generally called "chondroprotectives". They are differentiated as symptomatic slow acting drugs in OA (SYSADOA) and diseasemodifying OA drugs (DMOAD) [7]. Currently, glucosamine and chondroitin are the two most commonly used SYSADOA to modify the clinical and radiological course of OA. Glucosamine and chondroitin are also the most frequently used nutraceuticals in humans as well as in animals to alleviate pain associated with arthritis [8]. However, recent randomized controlled trials and a metaanalysis of these supplements have shown only small-tomoderate symptomatic efficacy in human OA [9]. A metaanalysis of clinical studies with glucosamine or chondroitin showed that only long-term daily administration for over 2 or 3 years may delay radiological progression of OA of the knee [10].

In the past twenty years some clinical studies have demonstrated the beneficial effects of native collagen type II in the treatment of patients with rheumatoid arthritis [11-14]. Crowley et al. [15] compared the safety and efficacy of undenatured collagen type II (UC-II) to glucosamine + chondroitin $(\mathrm{G}+\mathrm{C})$ in the treatment of patients with knee OA. The results of this randomized, double-blind clinical study indicate that UC-II treatment was more efficacious, resulting in a significant reduction in all assessments (WOMAC score, VAS score, Lequesne's functional index) after 90 days of treatment, whereas this effect was not observed in the $\mathrm{G}+\mathrm{C}$ treat-

\section{Wstęp}

Choroba zwyrodnieniowa stawów (ChZS) jest najbardziej rozpowszechnionym na świecie schorzeniem stawów. $W$ krajach zachodnich cechy radiologiczne tej choroby występują u większości ludzi powyżej 65. roku życia oraz u ok. 80\% osób w wieku powyżej 75 lat [1]. Ból i inne objawy ChZS mogą w sposób znaczący wpływać na jakość życia, oddziałując zarówno na jego aspekty fizyczne, jak i psychologiczne. Obecnie panuje powszechna zgodność opinii, że ChZS nie jest wyłącznie schorzeniem chrząstki, ale dotyczy również błony maziowej oraz leżącej poniżej tkanki kostnej [2, 3]. Tkanka kostna okołostawowa reaguje wytwarzaniem osteofitów, co prowadzi do jeszcze większego ograniczenia ruchomości stawów. Do degradacji chrząstki dochodzi w wyniku złożonych interakcji czynników mechanicznych i zmian biochemicznych w obrębie zajętego stawu.

Obecnie stosowane leczenie ChZS obejmuje gimnastykę, fizjoterapię oraz farmakoterapię [4, 5]. Najczęściej podawane preparaty to leki przeciwbólowe i niesteroidowe leki przeciwzapalne (NLPZ). Leki te skutecznie zwalczają ból związany z ChZS, jednak ich stosowanie może powodować poważne działania niepożądane ze strony układu pokarmowego i układu krążenia, szczególnie w przypadku ich długotrwałego stosowania [6]. Zasadniczym celem leczenia ChZS powinno być jednak spowolnienie zmian degeneracyjnych, a nawet wspomaganie odbudowy struktury chrząstki. Preparaty, które miałyby takie właściwości, są zazwyczaj określane jako „leki chroniące chrząstkę”. Dzielą się na grupę objawowych, wolno działających leków stosowanych w ChZS (symptomatic slow acting drugs in ostheoarthritis - SYSADOA) oraz grupę leków modyfikujących przebieg ChZS (disease modifying osteoarthritis drug - DMOAD) [7]. Glukozamina i chondroityna są obecnie najczęściej stosowanymi lekami SYSADOA, podawanymi w celu modyfikacji klinicznego i radiologicznego przebiegu ChZS. Ponadto glukozamina oraz chondroityna są nutraceutykami najczęściej stosowanymi u ludzi, jak również u zwierząt, do łagodzenia dolegliwości bólowych związanych z zapaleniem stawów [8]. Przeprowadzone ostatnio kontrolowane badania z randomizacją i metaanalizy tych suplementów wykazały jednak jedynie niską lub umiarkowaną skuteczność oddziaływania objawowego u osób z ChZS [9]. Metaanaliza badań klinicznych nad glukozaminą lub chondroityną wykazała, że jedynie długoterminowe, codzienne przyjmowanie leków przez 2 lub 3 lata może opóźnić radiologiczny postęp choroby zwyrodnieniowej stawu kolanowego [10].

Wiele przeprowadzonych w minionych dwudziestu latach badań klinicznych dowiodło korzystnego oddziaływania natywnego kolagenu typu II w leczeniu pacjentów z reumatoidalnym zapaleniem stawów (RZS) [11-14]. Crowley i wsp. [15] porównali bezpieczeństwo i skuteczność stosowania niezdenaturowanego kolagenu typu II (UC-II) z glukozaminą + + chondroityną $(G+C)$ w leczeniu pacjentów z chorobą zwy- 
ment group. Specifically, although both treatments reduced the WOMAC score, treatment with UC-II reduced the WOMAC score by $33 \%$ as compared to $14 \%$ in the $\mathrm{G}+\mathrm{C}$ treated group after 90 days. Similar results were obtained for the visual analog scale (VAS) score. Treatment with UC-II reduced Lequesne's functional index score by $20 \%$ as compared to $6 \%$ in the $\mathrm{G}+\mathrm{C}$ treated group at the end of 90-day treatment.

Our previous open clinical study in patients with $\mathrm{OA}$ showed that undenatured type I collagen (COL-I) (dietary supplement Colafit ${ }^{\circledR}$ made by Dacom Pharma s.r.o., Czech Republic) is effective in the treatment of OA [16]. Colafit is a pure atelocollagen type I isolated from bovine Achilles tendon. The term atelocollagen means that parts of telopeptides from both ends of the molecule are enzymatically removed but the helical structure is unchanged. Collagen type I is the most abundant collagen of the human body. It is found in tendons, skin, artery walls, the endomysium of myofibrils, fibrocartilage, and the organic part of bones and teeth. Lahm et al. [17] found that not only collagen type II, but also collagen type I is synthesized by the cells of the diseased cartilage tissue, shown by increasing amounts of collagen type I mRNA especially in the later stages of osteoarthritis.

The present randomized double-blind, placebo-controlled clinical trial evaluated the safety and efficacy of COL-I in the treatment of OA of the knee.

\section{Material and methods}

The study was conducted at 2 sites in Slovakia at the National Institute of Rheumatic Diseases, Piešt'any and at the Department of Orthopedics of F.D. Roosevelt Hospital, Banská Bystrica. The study enrolled 58 patients with radiographically confirmed painful knee OA grade 2 or grade 3 according to the Kellgren and Lawrence scale, who fulfilled the clinical criteria of the American College of Rheumatology (ACR) for knee osteoarthritis. Inclusion and exclusion criteria are shown in Table I. At the beginning of the study the consent form was discussed, signed and a physical examination was performed. The selected subjects were randomly assigned to receive COL-I (29 patients -12 males and 17 females, age $53.4 \pm 8.6$ years, mean \pm SD) or placebo (29 patients -13 males and 16 females, age $54.5 \pm 8.1$ years, mean \pm SD).

Study participants were instructed to take COL-I (8 mg pure lyophilized collagen type I in capsule) or placebo after morning fast with a cup of water. The placebo was comparable in all characteristics to the COL-I. After a 1-week NSAID or analgesics wash-out period, patients received either COL-I or placebo for 3 months, followed by an offtreatment period of 1 month to determine the carry-over effects of the drug. The $100 \mathrm{~mm}$ visual analog scale (VAS) rodnieniową (ChZ) stawu kolanowego. Wyniki tego badania klinicznego z randomizacją, przeprowadzonego metodą podwójnie ślepej próby wskazują, że skuteczność terapii UC-II była lepsza i doprowadziła do istotnego obniżenia wszystkich ocenianych parametrów [skala WOMAC (Western Ontario and McMaster Universities Index), wizualna skala analogowa (visual analogue scale - VAS), indeks czynnościowy Lequesne'a] po 90 dniach leczenia; natomiast w grupie leczonej $\mathrm{G}+\mathrm{C}$ nie zaobserwowano takiego wyniku. Mimo że obie terapie doprowadzity do obniżenia punktacji WOMAC po uptywie 90 dni, to jednak terapia UC-II obniżyła punktację WOMAC o 33\% w porównaniu ze zmniejszeniem o 14\% w grupie leczonej G + C. Podobne wyniki odnotowano w przypadku wizualnej skali analogowej (VAS). Terapia z UC-II doprowadziła do obniżenia punktacji indeksu czynnościowego Lequesne'a o 20\% w porównaniu z 6-procentowym obniżeniem w grupie otrzymującej G + C na koniec 90-dniowego czasu leczenia.

Wcześniejsze otwarte badanie kliniczne autorów przeprowadzone u pacjentów z ChZS wykazało skuteczność niezdenaturowanego kolagenu typu I (COL-I) (suplement diety Colafit ${ }^{\circledR}$ produkowany przez Dacom Pharma s.r.o., Republika Czech) w leczeniu ChZS [16]. Colafit jest czystym atelokolagenem typu I izolowanym z bydlęcych ścięgien Achillesa. Termin atelokolagen oznacza, że usunięto enzymatycznie fragmenty telopeptydów z obu końców cząsteczki, pozostawiając nienaruszoną strukturę helisy. Kolagen typu I to najbardziej rozpowszechniony kolagen w organizmie człowieka. Jest obecny w ścięgnach, skórze, ścianach tętnic, w śródmięsnej włókienek mięśniowych, chrząstce włóknistej i wchodzi w skład elementów organicznych kości oraz zębów. Lahm i wsp. [17] stwierdzili, że chorobowo zmienione komórki tkanki chrzęstnej wytwarzają kolagen typu II oraz COL-I, czego wyrazem jest narastanie stężenia mRNA dla COL-I, szczególnie w bardziej zaawansowanych etapach choroby zwyrodnieniowej stawów.

W badaniu klinicznym z randomizacją, przeprowadzonym metodą podwójnie ślepej próby i kontrolowanym placebo, oceniano bezpieczeństwo i skuteczność COL-I w leczeniu ChZ stawu kolanowego.

\section{Materiat i metody}

Badanie przeprowadzono w 2 ośrodkach na Słowacji, w Narodowym Instytucie Chorób Reumatycznych (National Institute of Rheumatic Diseases) w Pieszczanach oraz na Oddziale Ortopedii Szpitala im. F.D. Roosevelta (Department of Orthopedics of the F.D. Roosevelt Hospital) w Bańskiej Bystrzycy. Do badania zakwalifikowano 58 pacjentów z radiologicznie potwierdzoną bolesną ChZ stawu kolanowego 2. lub 3. stopnia w skali Kellgrena-Lawrence'a, którzy spetniali kryteria kliniczne Amerykańskiego Towarzystwa Reumatologicznego (American College of Rheumatology - ACR) dla ChZ stawu kolanowego. Kryteria włączenia i wykluczenia przedstawiono w tabeli I. Na początku omówiono i podpisano formularze zgody i przeprowadzono badania przed- 
Table I. Inclusion and exclusion criteria of the study group

Tabela I. Kryteria właczenia i wykluczenia chorych do badania

\begin{tabular}{|c|}
\hline Inclusion criteria / Kryteria włączenia \\
\hline Males and females 40-80 years old / Mężczyźni i kobiety w wieku 40-80 lat \\
\hline $\begin{array}{l}\text { Unilateral or bilateral OA of the knee satisfied Kellgren radiographic criteria grade } 2 \text { or grade } 3 \text { / Jedno- lub obustronna choroba } \\
\text { zwyrodnieniowa stawu kolanowego spetniajaca kryteria radiologiczne 2. lub 3. stopnia w skali Kellgrena }\end{array}$ \\
\hline VAS $\geq 40$ (pain in daily activities) / VAS $\geq 40$ (dolegliwości bólowe podczas wykonywania codziennych czynności) \\
\hline $\begin{array}{l}\text { Subject agrees not to start any new therapies for OA during the course of the study / Uczestnik zgadza się nie rozpoczynać } \\
\text { żadnych nowych terapii ChZS w czasie trwania badania }\end{array}$ \\
\hline Availability for duration of study period (4 months) / Dyspozycyjność na czas trwania badania (4 miesiące) \\
\hline Able to give informed consent / Zdolność do udzielenia świadomej zgody \\
\hline Exclusion criteria / Kryteria wykluczenia \\
\hline $\begin{array}{l}\text { Inflammatory arthropathy, rheumatoid arthritis, septic arthritis / Artropatia o podłożu zapalnym, reumatoidalne zapalenie } \\
\text { stawów, septyczne zapalenie stawów }\end{array}$ \\
\hline $\begin{array}{l}\text { Metabolic arthropathy (gout, pseudogout, Paget disease) / Artropatia o podtożu metabolicznym (dna, pseudodna, choroba } \\
\text { Pageta) }\end{array}$ \\
\hline Application of SYSADOA within the last 3 months / Stosowanie SYSADOA w ciagu ostatnich 3 miesięcy \\
\hline $\begin{array}{l}\text { Intra-articular corticosteroid, or hyaluronan injections in the target knee within the last } 3 \text { months / Iniekcje dostawowe } \\
\text { ze steroidami lub hialuronianem do wyznaczonego do obserwacji stawu kolanowego w ciagu ostatnich } 3 \text { miesięcy }\end{array}$ \\
\hline $\begin{array}{l}\text { Surgery of the targeted knee within } 6 \text { months before starting the study / Zabieg chirurgiczny w obrębie wyznaczonego } \\
\text { do obserwacji stawu kolanowego w ciagu } 6 \text { miesięcy poprzedzajacych rozpoczęcie badania }\end{array}$ \\
\hline
\end{tabular}

and Western Ontario and McMaster Universities Index (WOMAC Index) [18] were evaluated at the beginning of the study, after 3 months of treatment and after 1 month follow-up. Medication/supplement use and medical history were recorded. Paracetamol up to $4 \mathrm{~g}$ per day was allowed as a rescue therapy during the study. The possible side effects and medications used throughout the study period were recorded. The patients were also asked for verbal evaluation of the efficacy of the treatment by choosing from the following possibilities: excellent, good, mild or unsatisfactory. The study was approved by the Ethical Committee at the National Institute of Rheumatic Diseases.

Changes within the groups were calculated by ANOVA analysis with one nested variable.

\section{Results}

The results indicate that $\mathrm{COL}-\mathrm{I}$ treatment was effective, resulting in significant reduction in the WOMAC score and VAS score from the baseline after 3 months treatment and after 1 month follow-up. Treatment with COL-I reduced the total WOMAC score by $38 \%$ as compared to $10 \%$ in the placebo treated group and $37 \%$ vs. $8 \%$ after miotowe. Zakwalifikowanych uczestników przydzielono losowo do grupy otrzymującej COL-I (29 pacjentów: 12 mężczyzn i 17 kobiet, w wieku 53,4 $\pm 8,6$ roku, średnia \pm SD) lub placebo (29 pacjentów: 13 mężczyzn i 16 kobiet, w wieku 54,5 $\pm 8,1$ roku, średnia \pm SD).

Uczestnikom badania polecono przyjmować COL-I (8 mg czystego, liofilizowanego COL-I w kapsułce) lub preparat placebo na czczo przed śniadaniem, popijając szklanką wody. Placebo podawano w postaci w pełni porównywalnej z preparatem zawierającym COL-I. Po tygodniowym okresie odstawienia leków z grupy NLPZ i leków przeciwbólowych przez kolejne 3 miesiące podawano pacjentom COL-I lub placebo, po czym następował miesięczny okres bez przyjmowania leków w celu ustalenia odległego w czasie efektu przeniesienia. Ocenę przy użyciu skali VAS do 100 mm oraz indeksu WOMAC [18] przeprowadzano na początku badania, po 3 miesiącach leczenia oraz po uptywie miesiąca od jego zakończenia. Spisywano przyjmowane leki, suplementy i zbierano wywiad medyczny. W czasie badania dopuszczone było stosowanie paracetamolu w dawce do 4 g/dobę w ramach doraźnej terapii pomocniczej. Notowano ewentualne działania niepożądane i leki przyjmowane w czasie trwania badania. Poproszono również pacjentów o dokonanie ustnej oceny 
1 month follow-up (COL-I vs. placebo, $p<0.001$ ) (Fig. 1). COL-I treatment decreased the VAS score by $41 \%$ after 3 months treatment vs. 13\% in the placebo treated group and after 1 month follow-up 37\% vs. 11\% (COL-I vs. placebo, $p<0.001$ ) (Fig. 2). Efficacy of the treatment evaluated by patients showed significantly better efficacy in the COLI treated group compared to the placebo group (Fig. 3). Concomitant medication of the pain was needed only in 2 patients (paracetamol in an average dose of 600 $\mathrm{mg}$ /day, not longer than 2 weeks) compared with the placebo group in which 5 patients needed the rescue pain treatment (600 mg paracetamol 1-2 weeks). The tolerance of COL-I treatment was excellent: only one patient had to be withdrawn from the study due to dyspepsia; otherwise no side effects associated with treatment were observed.

\section{Discussion}

In our previous open clinical study undenatured type I collagen was shown to be effective in the treatment of OA patients [16]. The current double blind, placebo controlled study confirmed the clinical efficacy of COL-I in a larger group of patients with osteoarthritis. The results are similar to the results published by Crowley skuteczności leczenia, dając do wyboru następujące możliwości oceny: doskonała, dobra, mierna oraz niezadowalająca. Badanie zostało zatwierdzone przez Komisję Etyczną przy National Institute of Rheumatic Diseases.

Zmiany wewnątrzgrupowe obliczono metodą analizy wariancji ANOVA z jedną zagnieżdżoną zmienną.

\section{Wyniki}

Wyniki wskazują na skuteczność terapii COL-I, tj. istotne obniżenie punktacji w skalach WOMAC i VAS, w porównaniu z punktacją wyjściową, po 3 miesiącach leczenia oraz po miesiącu obserwacji. Podawanie COL-I spowodowało obniżenie łącznej punktacji WOMAC o 38\% w porównaniu ze spadkiem o 10\% w grupie otrzymującej placebo oraz o $37 \%$ vs $8 \%$ po miesiącu obserwacji (COL-I vs placebo, $p<0,001)$ (ryc. 1). Terapia z użyciem COL-I spowodowała obniżenie punktacji VAS o 41\% po 3 miesiącach leczenia w porównaniu ze spadkiem o 13\% w grupie otrzymującej placebo oraz o 37\% vs 11\% po miesiącu obserwacji (COL-I vs placebo, $p<0,001)$ (ryc. 2). Ocena skuteczności terapii wg pacjentów wykazała znamiennie wyższą skuteczność w grupie leczonej COL-I w porównaniu z grupą otrzymującą placebo (ryc. 3).

Zaledwie dwóch pacjentów wymagało jednoczesnego podawania leków przeciwbólowych (paracetamolu w śred-

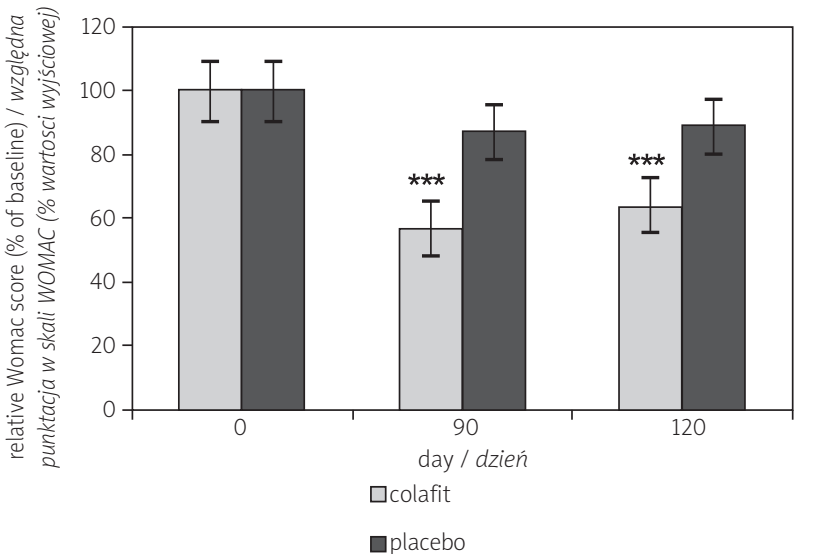

*** Significantly different from baseline / Znamienna różnica w stosunku do punktu wyjściowego $p<0.001$

Fig. 1. Changes in WOMAC scores at day 90 and 120 from baseline. WOMAC scores from each group were compared to the baseline value at specified time points. Each bar presents mean \pm SEM.

Ryc. 1. Zmiany w punktacji WOMAC w 90. i 120. dniu od punktu wyjściowego. Punktację w skali WOMAC dla każdej grupy porównano w określonych punktach czasowych z wartościami wyjściowymi. Każdy słupek przedstawia średnia \pm SEM.

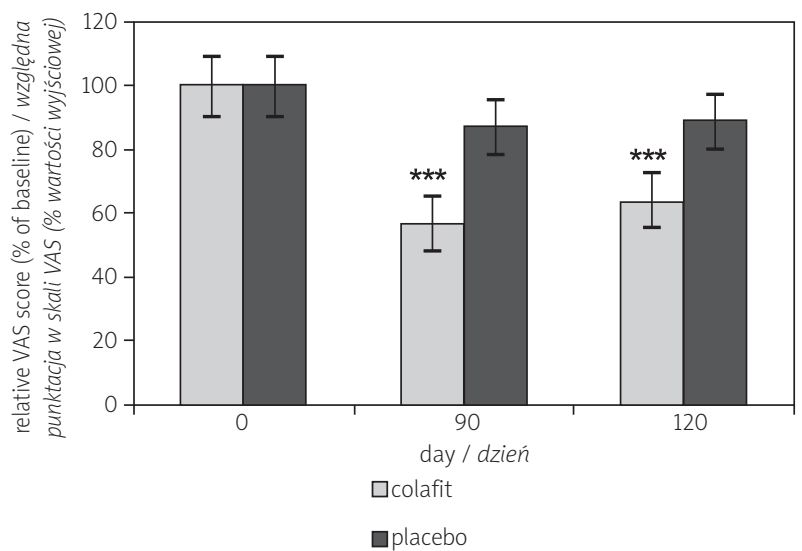

*** Significantly different from baseline / Znamienna różnica $w$ stosunku do punktu wyjściowego $p<0.001$

Fig. 2. Changes in VAS scores at day 90 and 120 from baseline. VAS scores from each group were compared to baseline value at specified time points. Each bar presents mean \pm SEM.

Ryc. 2. Zmiany w punktacji VAS $w$ 90. i 120. dniu od punktu wyjściowego. Punktacje w skali VAS dla każdej grupy porównano w określonych punktach czasowych z wartościami wyjściowymi. Każdy słupek przedstawia średnia \pm SEM. 

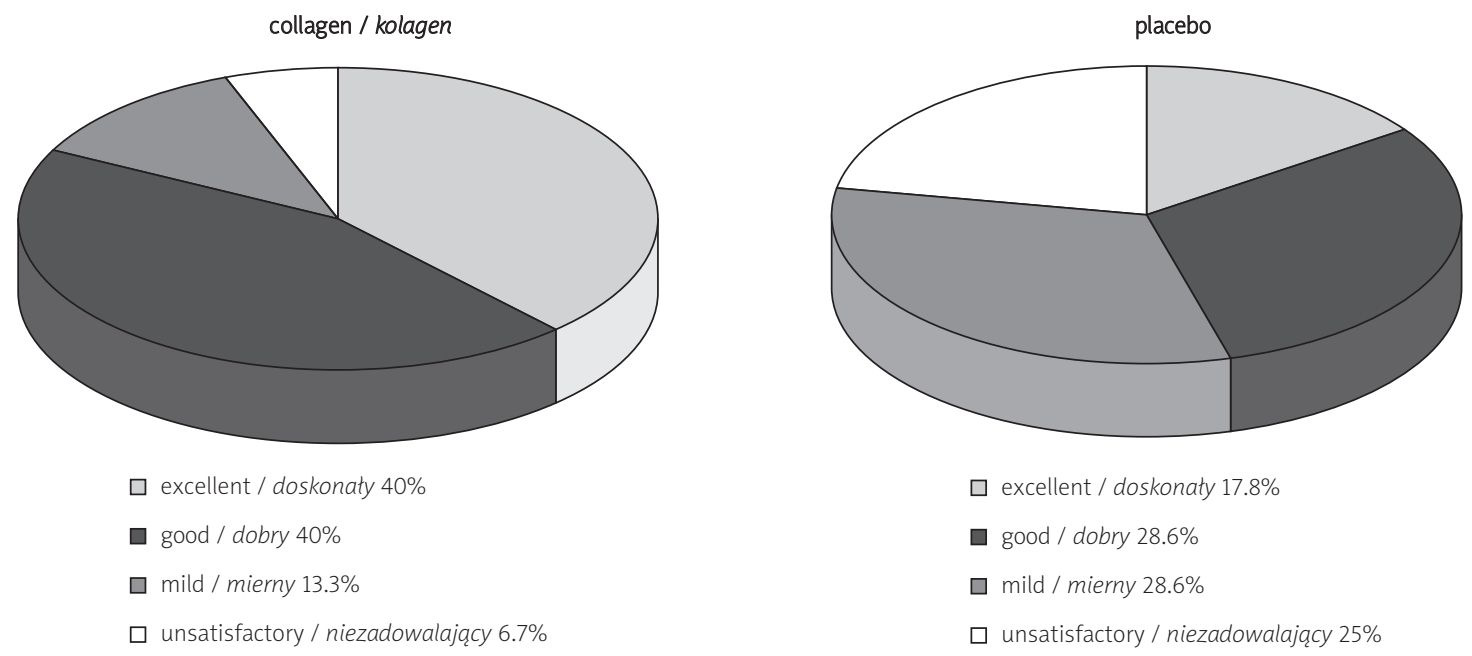

Fig. 3. Efficacy of the treatment evaluated by patients at day 90 of the study.

Ryc. 3. Skuteczność leczenia w ocenie pacjentów w 90. dniu badania.

et al. [15] in a clinical study with undenatured collagen type II in patients with knee OA.

The reduction of WOMAC index and pain VAS in both studies was similar. We suggested that these collagens could act by a similar mechanism in knee OA. The precise biochemical mechanism involved in COL-I induced pharmacological anti-arthritic effects in humans is not clearly established. Type I collagen is more abundant than collagen type II. It joint capsule, subchondral bone and also in osteoarthritic cartilage [19]. COL-I contains the amino acids required for the synthesis and repair of connective tissue throughout the body. Anti-inflammatory and anti-arthritic effects of collagen type I may be explained by the mechanism of oral tolerance developed after oral application of a small amount of collagen and induction of T regulatory (Treg) cells which produce antiinflammatory cytokines.

In conclusion, the findings of this study indicate that undenatured collagen type I is an effective treatment for symptomatic knee OA, even with a remote carry-over effect. In addition, it also has a very good safety profile.

The authors declare no conflict of interest. niej dawce 600 mg/dobę, nie dłużej niż przez 2 tygodnie) w porównaniu z grupą placebo, w której 5 pacjentów wymagało doraźnego stosowania pomocniczych leków przeciwbólowych (600 mg paracetamolu przez 1-2 tygodnie). Tolerancja leczenia COL-I była doskonała; z badania wykluczono jednego pacjenta z powodu niestrawności i poza tym jednym przypadkiem nie zaobserwowano żadnych działań niepożądanych związanych z leczeniem.

\section{Omówienie}

We wcześniej przeprowadzonym otwartym badaniu klinicznym dowiedziono skuteczności niezdenaturowanego COL-I w leczeniu pacjentów z ChZS [16]. Obecne, przeprowadzone metodą podwójnie ślepej próby, kontrolowane placebo badanie potwierdziło skuteczność kliniczną COL-I w większej grupie pacjentów z ChZS. Wyniki są podobne do wyników opublikowanych przez Crowley i wsp. [15] z badania klinicznego nad niezdenaturowanym kolagenem typu II u pacjentów z ChZ stawu kolanowego.

Stwierdzone spadki wartości indeksu WOMAC oraz punktacji skali bólu VAS w obu badaniach były podobne. Sugeruje się, że mechanizm działania omawianych kolagenów w ChZ stawu kolanowego może być zbliżony. Dokładny mechanizm biochemiczny zachodzący w wywołanych COL-I farmakologicznych działaniach antyartretycznych u ludzi nie został jeszcze do końca poznany. Kolagen typu I jest bardziej rozpowszechniony niż kolagen typu II, występuje również w więzadłach, ścięgnach, torebkach stawowych, warstwie podchrząstkowej kości oraz zmienionej osteoartretycznie chrząstce [19]. Kolagen typu I zawiera aminokwasy potrzebne do syntezy i naprawy tkanki łącznej całego organizmu. Działanie przeciwzapalne i działanie antyartretyczne COL-I moż- 
na wytłumaczyć mechanizmem doustnej tolerancji wytworzonej po doustnym podaniu niewielkiej ilości kolagenu i indukcji komórek T regulatorowych (Treg) produkujących cytokiny przeciwzapalne.

Podsumowując - wyniki badania wskazują na skuteczność działania leczniczego COL-I w objawowej ChZ stawu kolanowego, charakteryzującego się nawet odległym w czasie efektem przeniesienia. Ponadto COL-I ma bardzo dobry profil bezpieczeństwa.

Autorzy deklarują brak konfliktu interesów.

\section{References}

\section{Piśmiennictwo}

1. Arden N, Nevitt MC. Osteoarthritis: epidemiology. Best Pract Res Clin Rheumatol 2006; 20: 3-25.

2. Brandt KD, Radin EL, Dieppe PA, et al. Yet more evidence that osteoarthritis is not a cartilage disease. Ann Rheum Dis 2006; 65:1261-1264.

3. Lajeunesse D, Reboul P. Subchondral bone in osteoarthritis: a biologic link with articular cartilage leading to abnormal remodeling. Curr Opin Rheumatol 2003; 15: 628-633.

4. Fransen M, McConnell S, Bell M. Therapeutic exercise for people with osteoarthritis of the hip or knee. A systemic review. J Rheumatol 2002; 29: 1737-1745.

5. Das SK, Faroogi A. Osteoarthritis. Best Pract Res Clin Rheumatol 2008; 22: 657-675.

6. Moore RA, Derry S, McQuay HJ. Cyclo-oxydenase-2 selective inhibitors and non-steroidal anti-inflammatory drugs: balancing gastrointestinal and cardiovascular risk. BMC Musculoskelet Disord 2007; 8: 73.

7. Bruyère $\mathrm{O}$, Burlet N, Delmas PD, et al. Evaluation of symptomatic slow-acting drugs in osteoarthritis using the GRADE system. BMC Musculoskelet Disord 2008; 16: 165.

8. Brown LP. Pet Nutraceuticals; Inter-Cal Nutraceuticals. US: Arthritis Foundation. 2005.

9. Distler J, Anguelouch A. Evidence-based practice: review of clinical evidence on the efficacy of glucosamine and chondroitin in the treatment of osteoarthritis. J Am Acad Nurse Pract 2006; 18: 487-493.

10. Lee YH, Woo JH, Choi SJ, et al. Effect of glucosamine or chondroitin sulfate on the osteoarthritis progression: a meta-analysis. Rheumatol Int 2010; 30: 357-363.

11. Trentham DE, Dynesius-Trentham RA, Orav EJ, et al. Effects of oral administration of type II collagen on rheumatoid arthritis. Science 1993; 261: 1727-1730.

12. Barnett ML, Combitchi D, Trentham DE. A pilot trial of oral type II collagen in the treatment of juvenile rheumatoid arthritis. Arthritis Rheum 1996; 39: 623-628.

13. Ausar SF, Beltramo DM, Castagna LF, et al. Treatment of rheumatoid arthritis by oral administration of bovine tracheal type II collagen. Rheumatol Int 2001; 20: 138-144.
14. Wei, W, Zhang LL, Xu J-H, et al. A multicenter, double-blind, randomized, controlled phase III clinical trial of chicken type II collagen in rheumatoid arthritis. Arthritis Res Therapy 2009; 11: R180.

15. Crowley DC, Lau FC, Sharma P, et al. Safety and efficacy of undenaturated type II collagen in the treatment of osteoarthritis of the knee: a clinical trial. Int J Med Sci 2009; 6: 312-321.

16. Stančik R, Rovenský J, Zvarka J, et al. Undenaturated collagen type I in the treatment of painful osteoarthritis of the knee. Hungarien Rheumatol 2010; 3: 218.

17. Lahm A, Mrosek E, Spank H, et al. Changes in content and synthesis of collagen types and proteoglycans in osteoarthritis of the knee joint and comparison of quantitative analysis with Photoshop-based image analysis. Arch Orthop Trauma Surg 2010; 130: $557-564$

18. Bellamy N, Buchanan WW, Goldsmith $\mathrm{CH}$, et al. Validation study of WOMAC: a health status instrument for measuring clinically important patient relevant outcomes to antirheumatic drug therapy in patients with osteoarthritis of the hip or knee. J Rheumatol 1988; 15: 1833-1840.

19. Barley RD, Adesida AB, Bagnall KM, Jomha NM. Immunohistochemical characterization of reparative tissue present in human osteoarthritic tissue. Virchows Arch 2010; 456: 561-569. 